\title{
The perception of fear when using urban furniture
}

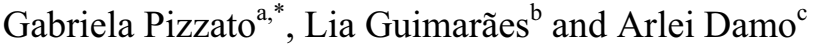 \\ ${ }^{\mathrm{a}}$ Department of Design and Graphic Expression, Federal University of Rio Grande do Sul -UFRGS, Av. Oswaldo \\ Aranha, 99/408. Porto Alegre, RS, Brazil \\ ${ }^{\mathrm{b}}$ Post Graduate Program in Production Engineering, Federal University of Rio Grande do Sul (PPGEP/UFRGS), \\ Av. Oswaldo Aranha, 99/5 floor. Porto Alegre, RS, Brazil \\ ${ }^{\mathrm{c}}$ Post Graduate Program in Anthropology, Federal University of Rio Grande do Sul (PPGAS/UFRGS), Av. Bento \\ Gonçalves, 9500 /43311. Porto Alegre, RS, Brazil
}

\begin{abstract}
This article presents a study on the perception of fear related to the use of three different types of urban furniture, qualitatively evaluated based on interviews while people were using them in the city of Porto Alegre, Brazil: the bus shelter, the playground, and the gymnastic equipment. The fear related to the lack of safety of the urban space was associated with the use of the three types of products. The fear experienced by the use of the playground and the bus shelter was related to the occurrence of accidents, since both products are often unsafe and do not fulfill ergonomic parameters. The fear experienced from the use of the gymnastic equipment is related to the possibility of incorrect use of the product and the occurrence of harassment. Both ergonomics and emotion are important aspects to be considered in design, in order to make the use of social/collective products a pleasant experience.
\end{abstract}

Keywords: emotion and design; ergonomics; collective product

\section{Introduction}

Emotion, satisfaction, and impression of users are fundamental in the development of products, interfaces, and environments [15]. Attention to the emotional dimension between users and products in the fields of Ergonomics and Design, as can be seen in important work achieved in our century $[4,5,7,10,15,17]$, have characterized emotions, such as pleasure, satisfaction, and affection, especially addressing products for personal use [4], or direct use [12]. The philosopher, Lacroix [2006], states that we live in a time in which emotion is worshiped, and is even being the subject of marketing. According to him, the issue of emotion has become, for some time now, an essential component of the promotional campaigns, where advertisers realized that emotion does sell [16]. But not just the advertisers: designer Marc Gobé in his first book Emotional Branding, emphasizes the importance of "connecting with the hearts of people," affirming that design can greatly assist companies to meet the expectations of its customers [14]. Emotion in Design is also a key word when it comes to innovation in the project [19], being associated with products that seek to provide pleasant experiences for consumers [17].

In this scenario, two questions were motivating for this work: (1) Do products of collective use generate emotional experiences? (2) Does the interaction of the users with products lead to negative emotional responses? Damásio [1996] answers them simultaneously by saying that material things evoke emotions, be them strong or subtle, positive or negative, conscious or not [1]. However, Hekkert [2008] understands that every encounter with a product generates an experience or a set of effects on the user. With that, he argues that the Design process can be driven by the intention to promote experiences previously defined [5]. Khalid [2006] states that understanding and reducing users' anxiety and fears (negative emotions) can help to increase satisfaction with products [10].

To meet these issues, this study addresses the emotional content of fear, a negative feeling of

\footnotetext{
*Corresponding author. Tel.: +55 513308 4262. E-mail address: gabriela.zubaran@ufrgs.br, gabrielazap@terra.com.br
} 
universal experience that is inherent to the human species. More specifically, the fear felt by users in the use of urban furniture: a product inserted in the urban environment and of strong collective interest, which has the role to contribute to the aesthetics and functionality of spaces, as well as promote the safety and comfort of its users [18].

\section{About the emotion of fear in sociology and anthropology}

Considered a primary and universal emotion, commonly associated with objects and negative situations, fear appears in the repertoire of basic emotions of most naturalist inspired researchers [8].

By definition, fear is an emotional state that results from the awareness that something real, imaginary, or caused can be threatening [9]. In a more physiological perspective, human fear is associated with the idea of preparing the body to react to a dangerous situation. For the sociologist Bauman [2008], the concept of fear is related to uncertainty, human ignorance of the threat, and what should be done about it [21]. In the studies of Elias and Delumeau it is also noted that fear arises associated with notions of danger and risk that may threaten the individual in their physical and social integrity, and in their self-image [6]. These authors show that fear is also a social orderly response to situations perceived as threatening. Thus, the universality of the experience of fear, which they attribute as an essence inherent in human beings, can be related to the fact that all societies, and the individuals who take part in these societies, deal with threats to a physical and social structure that is built, not guaranteed, nor certain.

The approach of different fears that may disturb people brings out the definition of close emotions, cited by Dias [2007], as the concepts of anxiety and anguish, which are associated to fear with special features: widespread fear, with feelings of restlessness and concern, and are less terrifying [9].

Barbalet [2001] states that fear, for human beings, is essentially social and relational: for example, the fear sensed is not exactly of the dark, but of what might happen in the dark [11]. From this point of view, individuals do not always fear just what they see or have actual knowledge of the sources of their fear. Bauman [2008] uses the classification of "derivative fear" or "secondary fear" - a stable social structure that can best be described as the feeling of being susceptible to danger; a sense of insecurity and vulnerability. He says that a person who has internalized a view of the world which includes insecurity will always call upon reactions favorable to an encounter with danger; derived fear acquires the ability to self-propel [21].

Regardless of the dangers we fear, the insecurity generated by it often leads people to affective or negative emotional reactions, causing discomfort and anxiety.

\subsection{Security: a basic need of the human being}

Humans are in a constant search of cognitive, affective, and emotional security, in the whole of their being [9]. However, without the feeling of insecurity it would sometimes be difficult to understand what our own safety is.

Insecurity can be tolerable, as long as it does not exceed the limits of reasonableness [9]. Dias [2007] believes that relative insecurity can compel us to grasp for reality and look for better solutions in life. But, according to him, this insecurity cannot become a constant factor of instability, and consequently, of human suffering, because human beings have basic needs that have to be met so that they are not surprised by the fear that insecurity can lead to [9].

Security is placed in Maslow's Needs Theory [13] at a level just above the basic needs, physiological (such as shelter, food, sleep).

They are the needs for security, or stability, such as protection against danger, disease, theft, and uncertainty. In the Needs Theory the most basic human needs have to be performed first so that the subsequent starts mattering. That is, human beings need to feel safe and confident, so that we can meet our social needs, of esteem and self-realization.

Darwin, one of the first to theorize about emotions, said that trust is the reverse of other emotions such as anxiety and discouragement, which he associates with inactivity, even leading individuals to isolation. However, trust leads to the positive encouragement of people to act [11].

\subsection{The fear of urban insecurity}

According to Rapoport [1973], the physical and spatial properties of the built environment are loaded with meanings that indicate to users the behavioral patterns expected or adapted, facilitating or inhibiting their use [3]. Assuming that the built environment is considered a means of nonverbal communication, it is possible to perceive the 
presence of insecurity in the cities, and the idea that fear, is everywhere. In Brazil, especially in large cities, the omnipresence of danger, the possibility of assaults, and robberies are part of everyday life [2].

Bauman [2009] dedicates his work - Trust and Fear in the cities to fear and urban insecurity, affirming that modern insecurity, in its various manifestations, is characterized by fear of crime and criminals [20].

In cities around the world we observe urban areas with houses built to protect its inhabitants, and not to integrate them in the communities to which they belong [20]. The city is full of walls, where physical barriers are built everywhere, in private and public places (around the plazas, condominiums, parks, schools, etc.). For the anthropologist, the new aesthetics of security decides the form of each type of construction, imposing a logic based on close observation [20].

Condominiums (physically isolated places located in the city, but socially and ideally outside it) are characterized by the ideal of keeping individuals considered socially inferior, at a distance - those who are unknown, "the foreigners" [20], whose presence generates fear, a source of anxiety, and aggression.

Streets, squares, and parks, public spaces where the urban furniture is located, regardless of the value and image they convey, are not excluded from urban life with its tensions and conflicts [2]. Given that the discovery of fear, in general, tends to lead individuals to seek protection and collection [9,20], a kind of rejection or disgust in regard to the use of public space and, consequently, to the urban furniture there, may occur. Regarding the elements studied, leisure activities that cater to practically all age groups (playgrounds and gymnastic equipment), and the use of public transport (bus shelters), which are critical to preserving the environment, are threatened.

\section{Method}

In order to identify the reasons why the contact of users with products for the use of specified groups [17] in daily practice might generate the experience of fear, we selected three different examples of furniture located in distinct points of Porto Alegre, in order to diversify both the public and the activities of the same target - a bus shelter, responsible for receiving users waiting for public transportation, a playground, recreation element used by children, and gymnastic equipment also used for leisure time, by public of different age groups. The study was conducted through a qualitative approach, where users were interviewed in usage scenarios, being evaluated within the context so that they could supply information about the elements studied and the spaces where they are set.

The three elements are inserted in middle class neighborhoods of the city, far from each other. The playground (Figure 1) is located in a small square that has residential buildings in the area surrounding it, and tends to be widely used by residents of the neighborhood and surrounding areas.

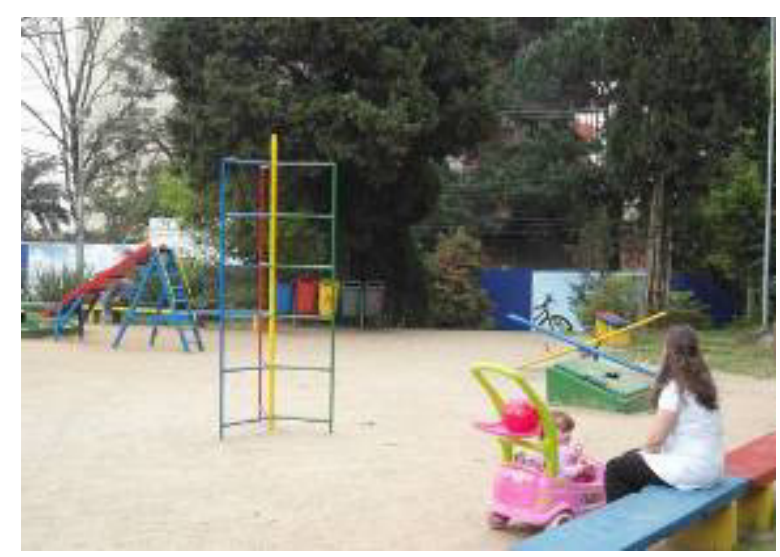

Fig. 1: The playground area

The bus shelter studied (Figure 2) is on an avenue that has intense flow of vehicles and is full of buildings.

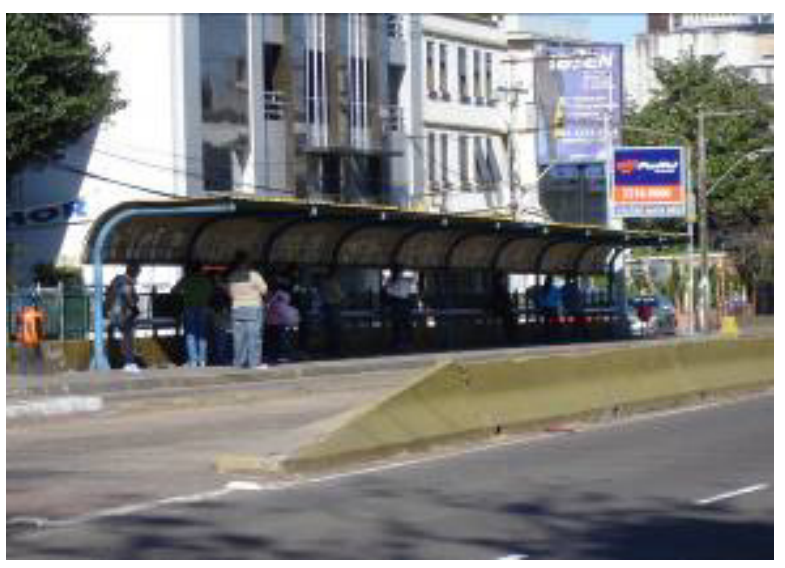

Fig. 2: A bus shelter placed on a city bus lane. 
The gymnastics equipment (Figure 3 and 4), called "gymnastics for senior citizens", is located on the shore of the Guaíba River, near an important and extensive leisure park in the city. Figure 4 shows the sign at the site that contains information about the device. Even though it is written on the sign that the place is not recommended for children, younger audiences often use the devices as a playground.

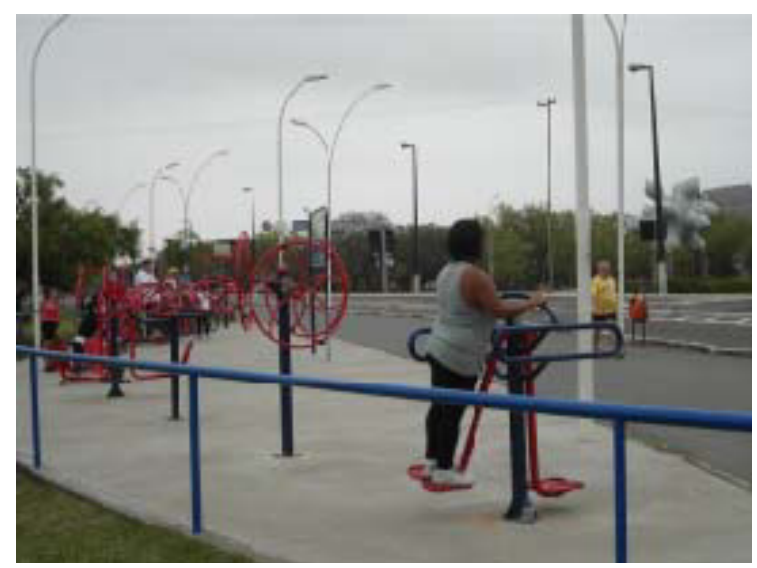

Fig. 3: Female user using the exercise equipment along the shore of the Guaíba River.

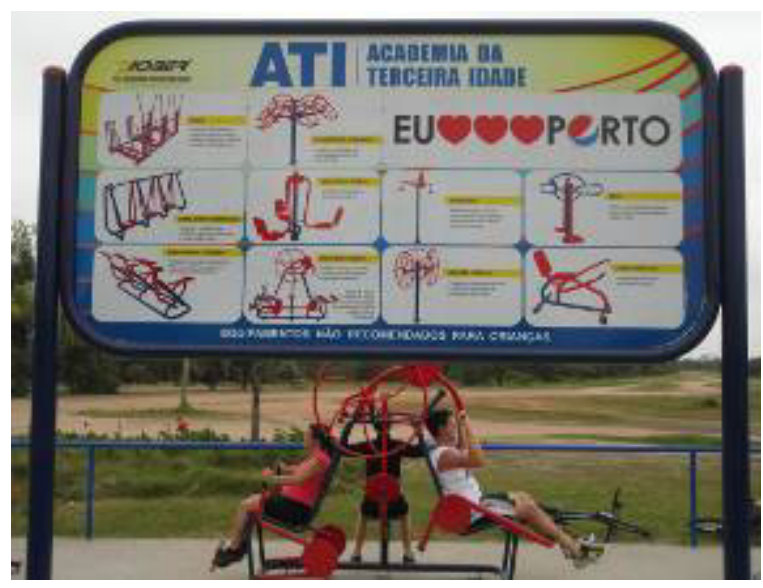

Fig. 4: Sign of "Gymnastics for Senior Citizens" containing illustrations of the apparatus, with an explanatory text next to it.

The interviews started with an open motivating question: "What do you think of this space?" even, if it were necessary, to reach a point "Do you feel safe in using this space?" A total of 60 interviews were conducted with 20 users from each area studied: 10 women and 10 men, with ages ranging from 20 to
60 years. We selected 45 statements out of the total, related to the experience of fear in the use of the three types of furniture analyzed, and later there was a comparison between the contents obtained in each type.

\section{Results}

The negative feelings expressed by users in the interviews originated from different sources and at the same time, common to more than one of the urban furniture studied, the reasons most mentioned by the users were chosen.

The fear of urban insecurity was unanimously cited by users in the three areas studied - being the greatest the threat to approach and/or attack by "strangers", the presence of "economically disadvantaged individuals", and those of "lower education". Moreover, fear of the presence of "bums" (the homeless), that appropriate public space to meet their physiological needs, cited by Maslow [13], bringing on the "despair" of some mothers (caregivers, in general) at the playground in fear that their children might witness scenes of sex and violence among the homeless.

As to urban insecurity, users of all spaces reported the wish for public surveillance and protection devices, such as fences and/or walls (next to the playground and gymnastic equipment), confirming the constant pursuit of human beings for security $[9,20]$ and the approval of the aesthetics of security [20].

Bauman [2009] believes that the uniformity of social space, accentuated by the isolation of living space of the residents, reduces tolerance towards differences, giving rise to mixofóbicas (segregation), making life in the cities look more "prone to danger," and thus more distressing [20]. The difficulty about the differences, according to Dias [2007], can be linked to aspects such as ethnicity, religion, political party, academic, among others. In addition, certain contexts and social or environmental factors are more likely to cause fear and insecurity in some age groups than in others [9].

The fear of sexual harassment was exposed only by women, when using the bus shelter and gymnastic equipment, where the "dirty pick up lines" and approach of men, users or non users, bring on "shame," "anger", and "fear". "Shame of the body" was also mentioned by some users.

Issues related to usability, fundamental condition for the quality of any product [13], were mentioned 
in the use of three elements: (i) in the bus shelter users reported feeling "fear of being in the wrong shelter", and thus "of getting on the wrong bus," because of the total lack of information about bus lines (common in the city bus shelters); (ii) of mothers (and other caregivers) users of the playground who showed fear of accidents, often caused by ergonomic problems (for example, incorrect sizing, inadequacy to the lower percentile and excessive height, etc.), and due to the poor state of conservation and maintenance of the playground equipment; and (iii) in the gymnastic equipment, as quoted by the female users, the difficulty in performing the exercises - "fear of working out in the wrong way," which can lead to injuries, and "shame of others" for using the device "incorrectly". As can be seen in pictures 3 and 4, the devices differ from those commonly used in gyms. In addition, the illustrations of the apparatus contained in the sign, do not have human figures and the elderly users cannot read the information due to the font size.

Figure 5 shows a detail of the slide. The part where the children end sliding down presents problems in terms of height (excessive for children) and position in relation to the circle - the projection of the end of the slide is outside the circle of sand, almost on the sandbox wall block.

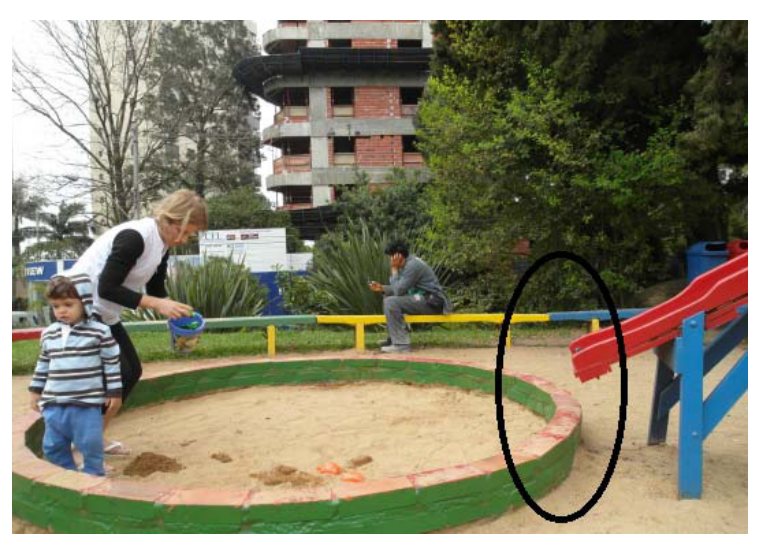

Fig. 5: Detail of the slide: danger when sliding down.

\section{Conclusion}

This article presented a study on the perception of fear, a sort of emotion universally experienced by many living beings, including humans. The study sought to draw attention to the manifestation of emotion in the use of urban furniture, especially in relation to the existence of negative emotions in users' interaction with these elements and the spaces in which they are. Three different types of urban furniture were qualitatively evaluated based on interviews while people were using them in the city of Porto Alegre, Brazil: the bus shelter, the playground, and the gymnastic equipment. The fear related to the lack of safety of the urban space was associated with the use of the three types of products. The fear experienced by the use of the playground (as expressed by the mothers) and the bus shelter was related to the occurrence of accidents, since both products are often unsafe and do not fulfill ergonomic parameters (i.e., the physical dimensions do not attend the correct percentiles). The fear experienced from the use of the gymnastic equipment is related to the possibility of incorrect use of the product (which is related to the product usability) and the occurrence of harassment (mainly assaults).

We raised some sources that induce to feelings of fear, leading the users that were studied to dissatisfaction and frustration in the use and interaction with the elements studied. In the interviews, we observed greater predisposition from women to acknowledge and/or explain the feeling of fear in the use of elements and their spaces.

The study points to important issues related to the theme of Ergonomics, Design, and Emotion, may be conducted back into the Design process in order to make the experience of using a socially significant product pleasant and enjoyable.

\section{References}

[1] A. Damásio, Design, Em busca de Espinosa: Prazer e dor na ciência dos sentimentos. São Paulo,Companhia das Letras, 2004.

[2] A. Serpa, O espaço público na cidade contemporânea, São Paulo, Contexto, 2007.

[3] A. T. L. Reis and M.C.D. Lay, Avaliação da qualidade de projetos - uma abordagem perceptiva e cognitiva, Ambiente Construído, Porto Alegre, v.6, n.3, 2006.

[4] B. Löbach, Design industrial - Bases para a configuração dos produtos industriais, São Paulo, Edgard Blücher, 2001.

[5] B. Russo and P. Hekkert, Sobre amar um produto: os princí pios fundamentais, in C. Mont'Alvão and V. Damazio (org), Design Emocional, Rio de Janeiro, Rocco, 2008.

[6] C.B. Rezende and M.CCoelho, Antropologia das emoções, Rio de Janeiro, FGV, 2010.

[7] D.A. Norman, The Design of Everyday Things, New York, Currency and Doubleday, 1990. 
[8] D. L. Breton, As paixões ordinárias. Antropologia das Emoções, Petrópolis, Vozes, 2009.

[9] F.N.Dias, O medo social e os vigilantes da ordem emocional, Lisboa, InstitutoPiaget, 2007.

[10] H. M. Khalid and M.G. Helander, Customer Emotional Needs in Product Design, Concurrent Engineering: Re search and Applications, v. 14, n. 3. 2006.

[11] J.M. Barlet, Emoção, Teoria Social e Estrutura Social, Lisboa, Instituto Piaget, 2001.

[12] L. A. Coelho, Conceitos-chave em design, Rio de Janeiro, Novas Idéias, 2008.

[13] L. B. de M. Guimarães, Ergonomia de Produto, vol 2. Porto Alegre, Feenge, 2006.

[14] M. Gobé, A emoção das marcas, Rio de Janeiro, Negócio Editora, 2002.

[15] M. Helander and M. Tham. Hedonomic - affective human factors design. Ergonomics, v. 46, n.13/14, 2003.

[16] M. Lacroix, O culto da emoção, Rio de Janeiro, José Olym pio, 2006.

[17] P. Jordan, Designing pleasurable Products: an introduction to the new human factors. London, Taylor and Francis, 2000.

[18] R. M. de Freitas, Mobiliário urbano, in J. L. Mascaro (org), Infraestrutura da Paisagem, Porto Alegre, Mais Quatro, 2008.

[19] W. Kindlein Jr, I. Collet and M.C. Dischinger, Desenvolvimento de texturas como fator de design emoci onal, in C. Mont'Alvão and V. Damazio (org), Design Emocional, Rio de Janeiro, Rocco, 2008.

[20] Z. Bauman, Confiança e medo na cidade, Rio de Janeiro, Za har, 2009.

[21] Z. Bauman, Medo líquido, Rio de Janeiro, Zahar, 2008. 